UDC 519.766.4

JEL Classification: F59

DOI: 10.15587/2312-8372.2019.188188

Kubiv 5.,
Balanyuk $\mathbf{Y}$.

\title{
DEVELOPMENT OF A COMBINED METHOD FOR PREDICTING DISCRETE TIME SERIES WITH NON-STABILITY FOR FORECASTING MILITARY GOODS DEMAND
}

Об’єктом дослідження є модель виробничої системи товарів військового призначення з нестаціонарними процесами. У дослідженні часових рядів характеристик виробничої системи різні конкуруючі моделі, як правило, отримуються у виробничих умовах із стохастичними даними стосовно виходу продукцї̈, що пояснюється проблемами вузьких місць. Отже, вибір найкращої моделі, що описує виробничу систему, стає складним та критичним, оскільки деякі моделі, які найбільш точно відповідають спостережуваним даним, можуть не передбачити майбутні значення відповідно до складності моделі. Це дослідження прагне продемонструвати процедуру вибору моделі у системі з випадковими даними за допомогою скоригованих вагових коефічієнтів. У даній роботі представлено метод поєднання двох наборів прогнозів. Отримані вимірювання служать вхідними даними до функції автокореляції та часткової функцї автокореляцї для отримання порядку прогнозуючих моделей. Параметри моделі оцінювали та використовували для прогнозування та порівнювали з вихідними та перетвореними даними для отримання суми квадратів помилок y (SSE). Потім моделі були піддані оцінці адекватності та згодом були протестовані за критеріями Аkаіkе ma Schwarz. Два окремі набори прогнозів даних часового ряду об'єднані для формування комбінованого набору прогнозів. Слід зазначити, що, коли кожен набір прогнозів містить деяку незалежну інформацію, комбіновані прогнози можуть дати покращення. Запропонований метод комбінування прогнозів дозволяе змінювати вагові коефіцієнти, що може призвести до кращих прогнозів. Основний висновок полягає в тому, що набір прогнозів може призвести до меншої середньоквадратичної помилки, ніж будь-який з початкових прогнозів. Минулі помилки кожного з початкових прогнозів використовуються для визначення ваги для приєднання цих двох оригінальних прогнозів при формуванні комбінованих прогнозів. Однак результативність прогнозу може змінюватися з часом.

Ключові слова: модель прогнозування, дискретний часовий ряд, випадкові вихідні дані, комбінований метод прогнозу.

\section{Introduction}

The planning processes for the production of military goods depend on the forecast of demand. The quality of planning depends on the accuracy of this forecast. This relationship is well documented [1-3]. The specifics of the products of this industry necessitated the development of appropriate approaches to forecasting, as it is influenced by a number of factors. Arms manufacturers are aware of significant risks, they need reliable methods for forecasting the demand for their products that would be workable in the early stages of the product life cycle [4, 5].

The choice of forecasting model has attracted a lot of attention over the past 30 years. There are many models to choose from - various forms of exponential smoothing, autoregressive integrated moving average (ARIMA) neural network grids, etc. - and in practice to choose which one to use [6].

Many theoretical and practical studies have studied various methods to identify the best model. If it is possible to determine the most suitable model for each time series, the forecasting accuracy can be significantly improved, as a rule, by $25-30 \%$ [7].

In general, forecasting software recommends or selects a model based on a statistical method. The effectiveness of candidate models is evaluated either by sampling data, usually using appropriate information criteria, or by removing a set of data points to create a sampling of validation (evaluation by sampling, [8]), also known as crossvalidation error). However, it is easy to develop examples where the choice of a statistical model (based on estimation in the sample or outside the sample) fails. Such cases are common in real forecasting programs and therefore make the choice of a forecasting model a non-trivial task in practice.

So, the choice of models of the corresponding forecasting models is an urgent problem. Thus, the object of research is a model of the production system of military goods with non-stationary processes. And the aim of research is increasing the forecasting efficiency of the behavior of 
the production system by developing a combined forecasting method.

\section{Methods of research}

Practitioners can apply judgment in various tasks in the forecasting process, namely:

1) determination of a set of candidate models;

2) model selection;

3) parameterization of models;

4) making forecasts;

5) refinement/adjustment of the forecast.

A very interesting case is when two (or more) forecasts are made for the same event. As a rule, the reaction of most statisticians and businessmen when this happens is an attempt to identify which is the best forecast; then the best forecast is accepted and used, and the second is rejected. Although this may have some merit when analysis is the main goal of the exercise, it is not a wise procedure if the goal is to make the best possible forecast, since a forecast is discarded almost always contains useful independent information.

This independent information can be of two types:

1. One forecast is based on variables or information that are not taken into account in another forecast.

2. When forecasting, other assumptions are made regarding the shape of the ratio of variables.

In particular, the second case does not necessarily lead to a situation where the combined forecast improves with the improvement of the individual forecast, although this is quite possible. It should be noted that one important condition is introduced about the nature of individual forecasts, namely, nonbias. The set of forecasts, according to which the true values are consistently reevaluated, in combination with a set of unbiased forecasts will lead to biased forecasts; most likely, combined forecasts give additional bias errors instead of objective forecasts. The first step is to verify that the individual forecast sets are unbiased; correction is possible in the presence of bias estimates.

Before discussing various methods of combining forecasts, let's give an empirical justification by making up the primary combination of the two forecasts. Selected forecasts relate to discrete time series data for which forecasts are made monthly for one period ahead [9]. The forecasts published in [10] confirm that the forecasting methods developed in the studies turned out to be so successful that it is necessary to look for processes for which alternative methods can be found which forecast is better.

There are many alternatives to exponential smoothing for making business forecasts, like neural networks and other machine learning methods. However, combined time series forecasting methods remain very attractive.

The combination is illustrated - the arithmetic mean for two individual forecasts. Table 1 shows the details for explanation.

A listing of these and other data forecasts is done at a later stage. At the moment, it is possible to simply note that the difference in errors in the three forecasts is 177.7 [6], 148.6 [1] and 130.2 (a combination with equal weights in each forecast). Thus, the predictions obviously have some value.

For a rational choice of the parameters of the combined forecast method, it is necessary, first of all, to select and justify the method for determining the weight coefficients.

Prediction errors

\begin{tabular}{|c|c|c|c|}
\hline \multirow{2}{*}{ Month } & \multicolumn{3}{|c|}{ Model } \\
\cline { 2 - 4 } & $\begin{array}{c}\text { Exponential } \\
\text { smoothing }\end{array}$ & $\begin{array}{c}\text { Box } \\
\text { Jenkins }\end{array}$ & $\begin{array}{c}\text { Combined } \\
\text { model }\end{array}$ \\
\hline January & 1 & -3 & -1 \\
\hline February & 6 & -10 & -2 \\
\hline March & 18 & 24 & 21 \\
\hline April & 18 & 22 & 20 \\
\hline May & 3 & -9 & -3 \\
\hline June & -17 & -22 & -19.5 \\
\hline July & -24 & 10 & -7 \\
\hline August & -16 & 2 & -7 \\
\hline September & -12 & -11 & -11.5 \\
\hline October & -9 & -10 & -9.5 \\
\hline November & -12 & -12 & -12 \\
\hline December & -13 & -7 & -10 \\
\hline Error variance & 196 & 188 & 150 \\
\hline
\end{tabular}

\section{Research results and discussion}

Although the combined forecast formed by providing the same weight for each of the individual forecasts is acceptable for illustrative purposes, however, when accumulating data, more weight is given to a set of forecasts containing less (mean square) errors. The problem is choosing the best approach to weighing a set of forecasts. There are many ways to determine these weights, and the goal was to choose a method that is likely to produce low errors for combined forecasts. It is assumed that the effectiveness of individual forecasts will be consistent with time in the sense that the variance of the errors for the two forecasts is indicated $\sigma_{1}^{2}$ and $\sigma_{2}^{2}$ can be minimized with an increase in the observation interval for all values of time $t$. In addition, it is assumed that both predictions will be indefatigable (naturally or after correction). A combined forecast is obtained by linearly combining two sets of forecasts, with a weight coefficient $0 \leq k \leq 1$ for the first set of forecasts and a weight coefficient $(1-k)$ for the second set, so that the combined forecast becomes unmoved. The error variant in the combined forecast $\sigma_{c}^{2}$ can be written as:

$$
\sigma_{c}^{2}=k^{2} \sigma_{1}^{2}+(1-k)^{2} \sigma_{2}^{2}+2 \rho k \sigma_{1}(1-k) \sigma_{2},
$$

where $k$ - the weight coefficient, which is given to the first set of forecasts, and $\rho$ - the correlation coefficient between errors in the first set of forecasts and errors in the second set. The choice of $k$ should be made so that the errors of the combined forecasts are the smallest, for which it is necessary to find the minimum of the total variance $\sigma_{c}^{2}$. Differentiating with respect to $k$ and equating the derivative to zero, let's obtain the minimum $\sigma_{c}^{2}$ that takes place under the following conditions:

$$
k=\frac{\sigma_{2}^{2}-\rho \sigma_{1} \sigma_{2}}{\sigma_{1}^{2}+\sigma_{2}^{2}-2 \rho \sigma_{1} \sigma_{2}} .
$$


When $\rho=0$, expression (2) reduces to:

$$
k=\frac{\sigma_{2}^{2}}{\sigma_{1}^{2}+\sigma_{2}^{2}} .
$$

It can be shown that if $k$ is determined by equation (2), the value $\sigma_{c}^{2}$ does not exceed the smaller of the variances $\left[\sigma_{1}^{2}, \sigma_{2}^{2}\right]$. To prove this, let's consider the relationship between variances $\left[\sigma_{1}^{2}, \sigma_{2}^{2}\right]$ in classical prediction with weighting coefficients $[k,(1-k)]$ and variance $\sigma_{c}^{2}$ in combined prediction. Under the conditions of stationarity and unbiased estimates, the variance of the prediction error $\sigma_{c}^{2}$ is [1]:

$$
\sigma_{c}^{2}=\frac{\sigma_{1}^{2} \sigma_{2}^{2}\left(1-\rho^{2}\right)}{\sigma_{1}^{2}+\sigma_{2}^{2}-2 \rho \sigma_{1} \sigma_{2}} .
$$

So,

$$
\left\{\begin{array}{l}
\sigma_{c}^{2}-\sigma_{1}^{2}=\frac{\sigma_{1}^{2}\left(\sigma_{1}-\rho \sigma_{2}\right)^{2}}{\left(\sigma_{1}-\rho \sigma_{2}\right)^{2}+\sigma_{2}^{2}\left(1-\rho^{2}\right)} \leq 0 ; \\
\sigma_{c}^{2}-\sigma_{2}^{2}=\frac{\sigma_{2}^{2}\left(\sigma_{2}-\rho \sigma_{1}\right)^{2}}{\left(\sigma_{2}-\rho \sigma_{1}\right)^{2}+\sigma_{1}^{2}\left(1-\rho^{2}\right)} \leq 0 .
\end{array}\right.
$$

That means $\sigma_{c}^{2} \leq \min \overline{\sigma_{1}^{2}, \sigma_{2}^{2}}$.

Thus, the combined forecast gives an improvement in all cases, except for the case when the modulus of the variance difference of the individual forecasts is a secondorder quantity of smallness, and the correlation coefficient $\rho$ is close to unity. Strictly speaking, this can be quite common.

Before the process of combining forecasts $(t=0)$, the optimal value of $k$ is unknown. The value of the weight coefficient $k$ changes as current information accumulates on the relative effectiveness of the two initial forecasts. Thus, the combined forecast $C_{T}$ for the observation period $T$ is more accurately written as:

$$
C_{T}=k_{T} \varphi_{1 T}+(1-k) \varphi_{2 T},
$$

where $\left[\varphi_{1 T}, \varphi_{2 T}\right]-$ forecast for the period $T$ from the first and second data sets, respectively.

Equations (2) and (3) are used as the basis for the development of certain forecasting methods. However, the effectiveness of any of the forecasting methods may change over time (for example, improve). Therefore, a method based on estimating the variance of errors over the entire observation interval from the beginning of the prophecy may thus become not optimal. It is necessary to build methods that provide more weight to the latest errors than those that were previously recorded.

\section{Conclusions}

Optimal preliminary identification of the best a posteriori model can bring significant advantages in predicting discrete, including non-stationary, time series. Research is now focused on automatic and statistical approaches to model selection.

However, users of forecasting methods often require systematic recommendations and application of judgment when choosing a forecasting model.
This paper presents a method for combining two sets of forecasts. It should be noted that when each set of forecasts contains some independent information, combined forecasts can provide an improvement. One important conclusion is that the proposed methods for combining forecasts allow to change weights, often leading to better forecasts. The proposed method differs in this from those methods that propose the use of constant weighting coefficients determined after receiving all individual forecast errors. Although the comments in this paper deal exclusively with the combination of two forecasts, there is every reason to combine more than two forecasts (where they exist).

Summing up, it is possible to say that there can be some benefit in comparing individual forecasts with a combined forecast. A combined forecast for a significantly smaller variance of errors than any single forecast provides that the models used for individual forecasts are capable of some improvement. Thus, one can get directions to search for a more accurate model that needs analytical value. It should be noted, however, that this model is adequate and fairly accurate, but it can be of two types. This can be a fundamentally different model, including a new variable or a different interpretation of the variable, or it can simply be confirmation of the model parameters. The problem of clarification of these non-stationary parameters is planned to be considered in the future.

\section{References}

1. Box, G. E. P., Jenkins, G. M., Siegel, A. F. (2016). Time series analysis: forecasting and control. London: Elsevier Inc., 622.

2. Petropoulos, F., Makridakis, S., Assimakopoulos, V., Nikolopoulos, K. (2014). «Horses for Courses» in demand forecasting. European Journal of Operational Research, 237 (1), 152-163. doi: http://doi.org/10.1016/j.ejor.2014.02.036

3. Priestley, M. B., Tong, H. (1973). On the Analysis of Bivariate Non-Stationary Processes. Journal of the Royal Statistical Society: Series B (Methodological), 35 (2), 153-166. doi: http:// doi.org/10.1111/j.2517-6161.1973.tb00949.x

4. Petropoulos, F., Goodwin, P., Fildes, R. (2017). Using a rolling training approach to improve judgmental extrapolations elicited from forecasters with technical knowledge. International Journal of Forecasting, 33 (1), 314-324. doi: http://doi.org/10.1016/ j.ijforecast.2015.12.006

5. Seifert, M., Siemsen, E., Hadida, A. L., Eisingerich, A. B. (2015) Effective judgmental forecasting in the context of fashion products. Journal of Operations Management, 36 (1), 33-45. doi: http://doi.org/10.1016/j.jom.2015.02.001

6. Kubiv, S. (2019). Approximations and forecasting quasi-stationary processes with sudden runs. Technology Audit and Production Reserves, 4 (4 (48)), 37-39. doi: http://doi.org/10.15587/ 2312-8372.2019.179265

7. Fildes, R., Petropoulos, F. (2015). Simple versus complex selection rules for forecasting many time series. Journal of Business Research, 68 (8), 1692-1701. doi: http://doi.org/10.1016/ j.jbusres.2015.03.028

8. Verbeek, M. (2017). A Guide to Modern Econometrics. Hoboken: John Wiley \& Sons, Inc., 508.

9. Greene, W. H. (2012). Econometric analysis. Upper Saddle River: Pearson Education, Inc., 1189.

10. Barnard, G. A. (1963). New Methods of Quality Control.Journal of the Royal Statistical Society. Series A (General), 126 (2), 255-259. doi: http://doi.org/10.2307/2982365

Kubiv Stepan, PhD, Associate Professor, Kyiv, Ukraine, ORCID: http:// orcid.org/0000-0002-1110-2024, e-mail: sikubiv@ukr.net

Balanyuk Yuriy, PhD, Associate Professor, Department of Information Security, National Aviation University, Kyiv, Ukraine, ORCID: http:// orcid.org/0000-0003-3036-5804, e-mail: lalink@ukr.net 